PINI IFERGAN

Bar-Ilan University, Israel

Recibido: 8/08/2015

piniifrgan@gmail.com

Aprobado: 6/05/2016

\title{
Hegel on the Absolute, with a Blumenbergian Twist
}

\section{El absoluto según Hegel, con un giro blumenbergiano}

RESUMEN: Este artículo no busca solucionar la cuestión del sentido y de la relevancia del concepto hegeliano de Absoluto. Más bien, busca arrojar nueva luz sobre la posibilidad de una relación con el Absoluto, que es, la posibilidad de que el Absoluto sea algo -una entidad con la que nosotros, en tanto que sujetos, podemos tener una relación real. Para la plausibiilidad de mi lectura del Absoluto, comienzo ofreciendo una interpretación del «Fragmento de sistema» de Hegel. Intento, entonces, dar sustancia a la idea de tal relación trayendo a colación el pensamiento de Hans Blumenberg, sorprendentemente, un pensador no hegeliano. Tras mostrar que también Blumengerg, pugna con la cuestión de nuestra relación con el absoluto, aunque en un contexto completamente diferente, arguyo que la lectura de Blumenberg del absoluto, como un transformdo contra el que la humanidad se posiciona persistentemente, sugiere una nueva dirección, plena de sentido, en los esfuerzos actuales para interpretar el Absoluto hegeliano. PALABRAS CLAVE: HEGEL - ABSOLUTO - ESPÍRITU - DIOS- HANS BLUMENBERG
ABSTRACT: This article does not seek to settle the question of the meaning and significance of Hegel's notion of the Absolute. Rather, it seeks to shed new light on the possibility of a relationship with the Absolute, that is, the possibility that the Absolute is something - some entity that we, as subjects, can have a real relation to. To make my case for the plausibility of my reading of the Absolute, I begin by offering an interpretation of Hegel's "System Fragment." I then attempt to add substance to the idea of such a relationship by adducing the thought of Hans Blumenberg, a strikingly 'non-Hegelian' thinker. After showing that Blumenberg, too, struggled with the question of our relation to the absolute, albeit in a completely different context, I argue that Blumenberg's reading of the absolute, as a backdrop against which humankind persistently positions itself, suggests a meaningful new direction in the ongoing efforts to interpret the Hegelian Absolute.

KEY WORDS: HEGEL - ABSOLUTE SPIRIT - GOD - HANS BLUMENBERG 


\section{Two Ways to Read Hegel's Absolute}

In this paper, I discuss the question of how our relation to the Hegelian Ab1 solute is to be understood. Hegel's Absolute is commonly understood in two opposed ways: on the one hand, the theological approach construes the Absolute (God) as that which is separate from us by definition, inasmuch as God created humans as mortal and limited; on the other, the philosophical approach to the Absolute construes it as a self-relation: the Absolute is that which fully comprehends itself as unified, non-self-limiting, free. On the former model, humans can indeed enter into a relationship with the Absolute, but it is a relationship that is inherently asymmetrical and distant. On the latter model, there can be no real, non-trivial, relationship with the Absolute, since everything is basically a manifestation of the Absolute.

It is also possible to approach the dichotomy with regard to the interpretation of the Absolute somewhat differently, and present it as a divergence from a perspective that frames the question about the Absolute analytically, asking whether it has independent substantive content.

Is Hegel putting forward a self-standing account of the Absolute, an account that isn't presented in terms of the history of philosophy or of religious or aesthetic praxis? Can we only describe the Absolute by describing the development of the various realms of knowledge of which it is composed, or can we articulate its nature in some other way? It might be suggested that the Absolute does, indeed, have a unique description that is not formulated in terms of its history and constituent elements. For it could be claimed that the self-standing description in question is a purely formal description, lacking any independent content whatsoever. In other words, not only is it not formulated in terms of God, or the ultimate, most evolved form of art or religion, but it speaks only of Spirit's «return to itself» and Spirit's attaining «full and complete self-knowledge»; to put it more 'ontologically,' it speaks of closing the gap between that which Spirit thinks, and that which is. Yet even were we to accept the claim that the purported self-standing account of the Absolute is nothing more than a formal condition that the Absolute must satisfy - namely, that the Absolute must have complete and exhaustive self-knowledge - it would nonetheless be the case that the description of the Absolute must still reflect all the various historical manifestations, i.e., modes of social and cultural organization, by means of which it is revealed and actualized. For these manifestations are not contingent, but necessary, aspects of the Absolute's self-knowledge and actualization. The fully comprehensive description of the actualized Absolute, the Absolute that has undergone the process of self-unfolding and self-understanding, is thus the description of that process of self-unfolding itself, rather than a description of a product of that process. 
Whether there can be an independent description of the Absolute, or all we have, at best, is a criterion for what would constitute a satisfactory description, this approach to discussing the Absolute sets out from the premise that the Absolute exists, and seeks to offer a detailed account of what that entails. It is, however, also possible to approach the Absolute from the opposite direction: instead of taking the Absolute as a starting point in need of elucidation, we can set out from the perspective of that which is not absolute, but finite, to use the Hegelian term, and investigate whether it is possible to render it infinite, that is fully self-aware, and fully self-actualized. This self-understanding is represented by arrays of human activity, such as art, religion, and philosophy, which engender the human contexts within which the finite imparts to itself infinite meaning and eternal existence.

Which starting point one adopts in seeking a reading of the Absolute - assuming its existence as that which is in the process of becoming fully actualized and has full self-knowledge, or taking the notion of the Absolute to be 'merely' a characterization of human activities that have attained full self-awareness reflects one's interpretive stance on Hegel's relationship to Kant's metaphysics. If we grant that Hegel accepts Kant's critique of metaphysics, we will have to choose the 'non-metaphysical' starting point, whereas if we view Hegel's thought as a reaction which attempts to repudiate Kant's critique and reinstate discussion of the Absolute, we will have to choose the 'metaphysical' premise. But one's choice of starting point is not solely an interpretive matter, for textual considerations also play a role. If one's primary source text is The Science of Logic, the metaphysical reading is more apt. But if the primary source text is the Encyclopedia of the Philosophical Sciences, where the transition from Objective Spirit to Absolute Spirit is compatible with construals on which the Absolute is understood as a description as well as construals on which the Absolute is understood as an actual state of affairs, it may be the case that the 'correct' reading is that which is able to meld the two construals into a single unified reading of the Absolute. Such a unified reading would presumably invoke a structure akin to Spinoza's 'single substance with two attributes' model. ${ }^{1}$

It is thus possible to frame the dichotomy between the theological and philosophical readings of the Absolute as a dichotomy between a metaphysical approach and a formal, non-metaphysical approach to the Absolute. And just as the Spinozistic model of substance might suggest a direction for bridging the gap between the metaphysical and the formal approaches, so too, with regard to the dichotomy between the theological and philosophical readings, there may be a middle ground.

[1] See Fulda 2003, 242-56. 
For might it be possible that Hegel had in mind another conception of the Absolute, a conception that marries features from both the theological and the philosophical models, rendering possible a genuine relationship between the individual and the Absolute? I will argue that in the «System Fragment» of 1800 , Hegel indeed sets out such a hybrid approach, an approach that cannot be construed in the classic sense of a reflecting subject's self-relation.

\section{Hegel's Absolute: An Undefendable Concept?}

The claim that Hegel's philosophy revolves around the Absolute and that, in many respects, the Absolute constitutes both its point of departure and its ultimate objective, should come as no surprise to anyone even vaguely familiar with Hegelian thought. Likewise, few would deny that a formidable challenge awaits present-day readers who seek not only to grasp what Hegel had in mind when he spoke of the Absolute, but more importantly, to arrive at a construal of the Absolute that is personally meaningful. It is safe to say that the concept of the Absolute seems utterly alien and farfetched to the contemporary mind. As Charles Taylor, who cannot be suspected of lacking sympathy for the Hegelian enterprise, puts it:

But how do we get from mere 'objective Spirit' to something absolute? ... If the development of Reason in history ... is in fact the necessary unfolding of the stages of Geist and Reason itself, then we have an unchallengeable grounding in reality and truth itself. But I don't suppose anyone can accept this today. (Taylor 1999, 158-59, italics added)

It is both thought-provoking and ironic that this profound sense of alienation is not the result of the tremendous change in the historical context from Hegel's day to our own, which has generated an unbridgeable gap - a veritable chasm - between us and Hegel. Rather, it stems from our whole-hearted adoption of a fundamental Hegelian insight: the Absolute does not fully reveal itself in its entirety from the outset, but rather, initially manifests itself as other-than-itself, a mode of presentation that expresses its essence only incompletely. What is this partial manifestation of the Absolute comprised of? It comprises an infinity of 'moments' of human activity as they are arrayed over the course of history. As partial expressions of the Absolute, these moments are necessary for the revelation of the Absolute in its entirety, which Hegel defines dialectically as the overcoming of fragmentation and self-otherness. In contemplating the Absolute, when we shift our focus from the Absolute itself to the means by which the Absolute is revealed, all we have are the historical manifestations - forms of social organization and human cultural developments - themselves, on their own, independent of their role in the Absolute's self-disclosure. And it is pre- 
cisely at the point where we accept this partial, contingent, historical existence as the only thing that can - from the perspective of human consciousness - be known and understood, that we lose the capacity to conceive of the Absolute as something real, self-standing, distinct from us. Paradoxically, then, Hegel's insight into the notion of the Absolute gives rise to total scepticism as to its feasibility, scepticism that is now, as Taylor noted, endemic.

But perhaps the matter is not as simple as this account implies. Beyond the irony and the resounding sceptical conclusion, we may sense that the alienation elicited by the notion of the Absolute has not, in fact, completely ruled out the possibility that there might nonetheless be something to this grandiose Hegelian idea. We may sense that although we question the notion of the Absolute, we do not reject it out of hand. For Taylor's remark can be taken as attesting to the conceivability of an Absolute, albeit an Absolute that is alien to us, though at the same time voicing doubt as to our ability to say anything significant about our connection to it. In this paper, I shift the focus from the intractable questions of what the Hegelian Absolute is (or how it became what it is) to the question of our relationship to the Absolute. More specifically, I pose the following question: does Hegel provide an account, not only of the unfolding of the Absolute in history, but also of our relationship to the Absolute once it has fully revealed itself as such?

To the Hegelian ear, the question of whether such an account of our connection to the Absolute has been given might appear to border on the illegitimate, or to indicate a lack of familiarity with Hegel's core vision of the Absolute. For surely, students of Hegel might claim, our inability to engage with, let alone confront, the Absolute, dictates, from the outset, that our relationship to the Absolute is itself a facet of the Absolute; hence to construe our relationship to the Absolute as a problem that we must address is to assume that we are distinct from the Absolute, an assumption contrary to Hegel's core concept. This is a potent argument that compels me to clarify the legitimacy of my claim that the nature of the Absolute - as conceived by Hegel himself - does not preclude our taking it as a separate and distinct object of scrutiny. Only after the feasibility of doing so has been established will we be able to move on to assessment of the adequacy of Hegel's elucidation of our relation to the Absolute, and to my own suggestions about how the relationship might be fruitfully understood. In making these suggestions, I draw on Hans Blumenberg's approach to the said relationship. Though formulated in a very different context, his approach provides significant insight into what the Absolute might mean to us today. 


\section{Reading Hegel’s «System Fragment»}

Let us first turn to Hegel and explore whether it is possible to validate my framing the question of our relation to the Absolute as a problem. A good point of departure is the essay known as the «System Fragment» of 1800 (Hegel 1961 [1800]), which not only sets forth one of the first formulations of Hegel's notion of the Absolute, but more importantly, also explicitly engages with the question of the individual's relationship to the Absolute. Hegel asserts that unity must be regarded as a self-particularizing, self-differentiating multiplicity. In essence, this description of an initial unity that becomes fragmented into particularized units already suggests that the relationship between the Absolute and the individual is problematic. An individual element within this self-differentiation can be contemplated either via its relationship to all the other elements - that is, in terms of its place within the manifold of unified particulars - or by differentiating it from these other particulars as an element that stands in juxtaposition to them, and negates them. On the former construal, that is, if the individual is construed in terms of its place within the manifold, the individual cannot be grasped as fully distinct, but must be grasped in terms of its situation relative to other individuals in the 'unity that is a multiplicity.' The second option, which defines the individual, not in terms of its position relative to the other particulars, but in contradistinction to the other particulars, thus appears to be more promising. This construal views the individual as defined by its being juxtaposed to, and separate from, the other particulars; it is this oppositional relationship that renders the individual independent.

The continuation of the «System Fragment» makes it clear that Hegel favours this option, that is, favours construing the individual as gaining an independent identity through separation, even if this separation is constrained from the outset by the primordial unity with respect to which - or in opposition to which - the separation is defined. Note, however, that to argue that for Hegel, the separation imperative is more compelling than the construal on which individual is defined and rendered unique by its role within the manifold, is to adopt the vantage point of the individual. On this perspective, the individual, cognizant of his reliance on others, seeks to frame his separation not simply in terms of negation, of what she is not, but affirmatively as well, in terms of her uniqueness, her particular and distinct selfhood.

Now it might be claimed that, if we assume that the individual's impulse toward separation is indeed the crux of the matter, then we need not give further consideration to the other perspective, namely, the perspective of the initial self-differentiating unity itself, and we can restrict ourselves to examining the interactions between individuals who seek to define their own uniqueness through their mutual relations. But to adopt this approach would 
in effect be capitulation to the very scepticism about the Absolute that Taylor spoke of, and Hegel does not choose this easy way out. He does not make do with considering the individual solely in terms of the interrelations in which she takes part, interrelations that, viewed in aggregate, generate a closed and self-sufficient totality. In place of this constructivist approach, Hegel approaches the individual, not only in terms of the separation imperative, that is, in terms of the individual's willingness to stand up to the totality she seeks to separate from, and in defiance of which she takes actions that mark her as unique, but also from the opposite perspective, the perspective of the Absolute. In one of the key sentences in the opening section of the «System Fragment,» Hegel frames the individual-totality relationship as a kind of reciprocal dependence:

Der Begriff der Individualität schließt Entgegensetzung gegen unendliche Mannigfaltigkeit und Verbindung mit demselben in sich; ein Mensch ist ein individuelles Leben, insofern er ein anderes ist als alle Elemente und als die Unendlichkeit der individuellen Leben außer ihm; er ist nur ein individuelles Leben, insofern er eins ist mit allen Elementen, aller Unendlichkeit der Leben außer ihm. (TWA1, 419-20)

The concept of individuality includes opposition to infinite variety and also inner association with it. A human being is an individual life in so far as he is to be distinguished from all the elements and from the infinity of individual beings outside himself. But he is only an individual life in so far as he is at one with all the elements, with the infinity of lives outside himself. (Hegel 1961 [1800], 310)

Even in this early rendering, we can discern an essential feature of Hegel's mature concept of the Absolute, formulated after he had worked out the concept of Spirit, namely, the reciprocal dependence between the finite and infinite, between the totality and the particulars of which it is comprised. But conspicuously missing here (and developed by Hegel later, in the Jena writings and the Phenomenology of Spirit) is a description of this mutual dependence in terms of the idea of the one's being an expression of the other - and vice versa - a description that explains the structure of the relationship between the totality itself and its component parts.

Some have claimed that once Hegel articulates both the notion of the Spirit, and the idea that Spirit, and the particulars of which it is comprised, are really expressions of each other, the option of defining separation in terms of an oppositional relation to the Absolute, and interpreting the relationship between the individual and the Absolute as oppositional, as premised on robust separation, becomes moot, and instead, the relationship posits a separation that is no more than the reflexive relation of 'self-otherness.' Is this indeed the case? 
Does construing the relationship between the Absolute and the particulars that comprise it in the strong sense of 'standing up to,' of robust separation-even though the separating particular is at the same time an integral part of the Absolute-really become moot? Those who seek to claim that it does will adduce the continuation of the «System Fragment» to show that the relationship between the totality (the Absolute) and its components can be understood as oppositional only on the theological premise that there is a fundamental distinction between divine infinitude and human finitude. They will cite as compelling proof of this Hegel's assertion that the gap, the fundamental separation between the finite and the infinite, is bridgeable only by way of religion and its rituals - ritual sacrifice, for instance, as Hegel notes in the «System Fragment» - and not by way of philosophy. Moreover, since, on my reading of Hegel's view, philosophy is grounded in reflection, and the reflective stance both causes the separation, and perpetuates it, philosophy's inability to bridge the gap is not contingent, but of the essence. Those who argue that the 'separation imperative' construal of the individual-Absolute relationship is moot in Hegel's mature philosophy insist that setting aside theology and pursuing philosophy in its stead makes it possible to relinquish engagement with the question of the relationship between man and the Absolute, since philosophy conceives of the Absolute solely as a self-relation, that is, it takes the Absolute to be identical to the Absolute's relation to itself.

I will now propose a different way to read the «System Fragment,» a reading on which there is continuity between the «System Fragment» and Hegel's more developed doctrine of Spirit. The «System Fragment» seeks to describe and explain how the separation came about, and how it might be overcome. It tells us that the individual is grasped as such only within a broader framework - the Absolute. And it is not merely part of the totality, but rather, its connection with the Absolute is a 'default' position, so that even after the process of self-awareness and recognition of its uniqueness, followed by its separation, the individual is still imbued with longing to return to the Absolute and be part of it. Nevertheless, separation is indeed a necessary condition for the individual's emergence as such, for its full identity as a discrete particular. If this characterization captures Hegel's intent in the «System Fragment,» then it seems to me we must conclude that his supposed abandonment of the theological solution in the Jena writings and the Phenomenology of Spirit does not, in fact, reflect a major shift in the underlying issue Hegel is addressing, but rather its reframing as a philosophical problem. This reframing does not mean that the issues that motivated the «System Fragment» have been set aside, but that they are now formulated in a manner that focuses on understanding the Absolute and its development. This change in focus - from the process that engenders the autonomous, non-dependent individual, who is nonetheless conscious of 
the fact that her dependence is a necessary condition for the possibility of her independence, to the process of the Absolute's development - arises from the nature of the former process. When the autonomous individual's perspective is the point of departure, the impulse to achieve separation is well-grounded, but there is no good explanation for the inherent impulse to return to the original context from which the individual sprang, and on which her unique identity depends. Only when separation from the Absolute is grasped as profoundly connected to the manner in which the Absolute comes to understand itself through the individual's quest for independence can we avoid the problematics of the individual's desire to return to its pre-separation origins, to return to and be part of the Absolute. For in essence, the individual never separates from the context that makes the quest for separation possible, and that context - the Absolute - is, in effect, part of that quest. The Absolute is an integral part of the project of separating from the Absolute. Hence the explanatory focus cannot be the individual's effort to gain independence, but must be the Absolute from and through which the individual strives to be independent.

But is the price that Hegel pays for this change in perspective too steep? If the reason for the shift is the need to ground the possibility of independence despite the Absolute - and indeed, the Absolute develops into the Absolute precisely through the individual's insistence on independence - then when all is said and done, is it not the case that the Absolute is all there is? That is, is it not the case that the individual is merely an expression of the Absolute, an expression that achieves uniqueness only insofar as it contributes to rendering the Absolute itself independent?

To avoid this problematic conclusion, we must, though conceding that we are part of the Absolute, return to the question of the individual's relation to the Absolute - the individual's standing up to the Absolute, juxtaposing herself to the Absolute, opposing the Absolute. This return cannot be achieved by reverting to the stance of the «System Fragment, point of the individual seeking independence from the Absolute, and instead, taking the Absolute as a given, inquire into the meaning of our inexorable, irrevocable connection to it. Admittedly, here Hegel leaves readers in the dark in two respects: his presentation of the problem of the individual's relation to the Absolute as a question is very vague, and his account of the Absolute itself, which could shed light on that relation, is relatively 'thin.' This seems to leave us with no choice but to acquiesce in one of the following options. The first is a kind of quasi-theological or 'onto-theological' approach that guarantees the existence of the Absolute as an entity, an ontological reality, to which we have a relation. Proponents of this approach attempt to show that although they invoke a 'theological' model, the 'theology' in question is not a traditional 'revealed truth' theology, but rather, a philosophy of the absolute Spirit. The 
other option restricts the import of the Absolute to the realm of what Hegel calls «objective Spirit» - the objectification of consciousness in civil institutions such as property, courts, etc. - and seeks to show why the Absolute must be understood as describing a certain state of affairs, namely, the conditions that can be demonstrated to be the optimal conditions for individuals to achieve self-determination. In stipulating these conditions, no ontological claims are made, but rather, Hegel describes a framework for social and cultural interaction between many people, a framework within which the individual can determine and validate her identity.

The former option, that is, the 'theological/onto-theological' approach, is preferable, not only because it appears to be the more faithful reading of Hegel's stance, but more importantly, because it acknowledges that it is not possible, as a matter of principle, for the individual's self-determination, or validation of that self-determination, to be based on the inter-subjective interactions that, in aggregate, constitute objective Spirit. This approach comprehends that there must always be a gap between the aggregated interactions of individuals, interactions by means of which the individual achieves self-determination, and the source that confers validity and justification on that process of self-discovery. To formulate this in Hegelian language, absolute Spirit needs its prior manifestations as subjective Spirit and objective Spirit because these stages enable the individual to achieve self-justification and self-validation, that is, to determine and affirm herself both by means of inter-subjective interactions, and at the same time, by transcending them. The individual's transcendence of her routine social intercourse confers on the Absolute, or absolute Spirit, a unique status. For the Absolute is the locus of the shift from the state of affairs in which the individual's quest for self-determination is contingent and one-sided, to a state of affairs where the individual's quest for self-determination is a necessary element of, and thus fully in harmony with, the system that gives rise to it. This necessary process of transcending, which is intended to ground the individual's self-affirmation and self-determination, however, creates a gap, and it is this gap that brings to the fore the problem of the individual's relation to the Absolute. The gap emerges because although we can comprehend the necessity of transcending one's routine social intercourse, this in itself does not answer the question of our relation to that which compelled us to undertake this transcendence for the sake of becoming who we are.

Clause 553 of the Encyclopedia of the Philosophical Sciences - the clause that opens the section on the Absolute Spirit-summarizes the question in Hegel's characteristically obscure language:

Der Begriff des Geistes hat seine Realität im Geiste. Daß diese in der Identität mit jenem als das Wissen der absoluten Idee sei, hierin ist die notwendige Seite, daß 
die an sich freie Intelligenz in ihrer Wirklichkeit zu ihrem Begriffe befreit sei, um die dessen würdige Gestalt zu sein. Der subjektive und der objektive Geist sind als der Weg anzusehen, auf welchem sich diese Seite der Realität oder der Existenz ausbildet. (TWA10, 366)

The concept of spirit has its reality in spirit. For this reality, in identity with the concept, to exist as knowledge of the absolute idea, what is necessary is that the implicitly free intelligence should in its actuality be liberated to its concept in order to be its fitting shape. Subjective and objective spirit have to be seen as the road along which this aspect of reality or existence develops. (Hegel 1997 [1830], 138)

I cannot provide a detailed analysis of this important paragraph here, but let me summarize its import. The opening statement that the actualization of the concept of Spirit lies in Spirit itself is essentially making a declaration as to Spirit's absolute nature, its independence of everything but itself. The final sentence contends that absolute Spirit's uniqueness is determined by the experiences it underwent as subjective Spirit and objective Spirit, by means of which Spirit as concept becomes identical to its actuality. Both these readings are endorsed by most Hegel scholars. The interpretation of the middle sentence, however, is more controversial. It can be argued that the second sentence describes one who has grasped the concept of absolute Spirit, that is, it describes the individual, the finite consciousness, who, having gone through the earlier stages in Spirit's development, is ready to know the Absolute, namely, the entity that is self-actualizing. But if so, we might argue that it is legitimate to question whether the concept of Spirit, which entails its own actuality, is dependent on the existence of a finite consciousness that is cognizant of it. Perhaps this quandary is no more than a misunderstanding that can be resolved by noting that the cognizing subject must be grasped as part of the development of Spirit itself, and indeed, the cognizing subject is simply an aspect of Spirit's own self-knowledge. In any event, I will not focus on such quandaries, but mention them only to point out that the fact that these sorts of 'riddles' are frequently raised, and the very ambiguity of Hegel's account of the Absolute, should be seen as inviting us to reconsider the question of the relation between the individual and the Absolute. Tellingly, it is precisely when the Absolute achieves its full actualization, truly becoming absolute, that this question comes to the fore. On a personal note, vis-à-vis what philosophers of science call 'the context of discovery,' my interest in trying to pin down Hegel's stance concerning this question was stimulated by the fact that despite repeated readings of the passages in the Hegelian corpus that directly address the concept of the Absolute itself - not its potential, not its unfolding, but the Absolute as actualized - I always came away with the impression that the discussion was not pursued as far as 
it could go, and that Hegel transitioned to other concepts, often theological, aesthetic, or political, a bit too quickly.

\section{A Blumenbergian Twist}

I will now attempt to narrow the explanatory gap with regard to our relationship to the Absolute by adducing the philosophy of Hans Blumenberg. In so doing, I am not claiming that this particular question, in its Hegelian context, was addressed by Blumenberg, but only that Blumenberg's discussion of the notion of the absolute sheds light on the question we are considering. I will focus mainly on Blumenberg's concept of the «absolutism of reality.» The concept of the "absolutism of reality» is introduced in the opening chapter of Blumenberg's Work on Myth. Blumenberg deftly elucidates his idea in the epigraph that graces this chapter - a quote from one of Franz Kakfa's letters to his friend Max Brod:

They could not put the determining divine principle at sufficient distance from themselves; the whole pantheon was only a means by which the determining forces could be kept at a distance from man's earthly being, so that human lungs could have air. (Blumenberg 1985, 3)

The possibility of human existence is predicated on the distance that we manage to put between ourselves and a certain existential reality, the only thing that can be said about which with any confidence is that, were it not for that distance, human life would be impossible. In other words, human existence is profoundly dependent on keeping our distance from an entity that can be characterized as absolute precisely because of the totality of the do-or-die nature of our relationship to it. Blumenberg, seeking to define the «absolutism of reality,» further develops the idea expressed in the epigraph:

Absolutism of reality. What it means is that man came close to not having control of the conditions of his existence and, what is more important, believed that he simply lacked control of them. (Blumenberg 1985, 3-4)

Blumenberg's definition of the «absolutism of reality» does not appear to touch on the objective side of the reality that is characterized as «absolute.» Rather, it emphasizes the subjective side - the conscious moment when man feels, or believes that he feels, that he is about to lose control over the necessary conditions for maintaining his existence. From the continuation of Blumenberg's account, however, it becomes abundantly clear that what led to the moment of trepidation was a change in man's physical attributes and abilities as a result of evolutionary adaptation to the changed environmental conditions under which he lived. According to Blumenberg, this critical change was man's 
pre-historic transition from walking on all fours to the upright, two-legged stance. The change marks the moment in human pre-history when man's perceived harmony with his environment was disturbed, as from that moment on, the changed environment, now viewed as threatening due to man's expanded field of vision and exposure to the wide-open horizon, became an absolute that imperilled human survival.

The absolute's emergence as a problem also marked the emergence of the problem of man's relation to the absolute, as it was now clear that one's existence depended on the manner in which one contended with the absolute. Yet the absolute was not something foreign, but was that which made existence possible. Blumenberg, who is committed to an anthropogenic description, defines the formative moment as a «situational leap.» It is the moment when the human race - not, admittedly, the individual who seeks independence, as in the Hegelian context - differentiated itself from the absolute. Juxtaposing itself to, and positioning itself in opposition to, the conditions vital for its existence, the human race in essence separated itself from the absolute, and in so doing, construed human existence as a problem.

Hegel presents the idea of separation as a problem inherent in existence itself, though it can only be grasped, described, and explained through the medium, the vehicle, of man. Blumenberg, by contrast, takes separation to be an arbitrary phenomenon that, given the human propensity to devise concepts or symbols, comes to play an explanatory role. It is striking that although the metaphysical dimension of the Hegelian account is absent from the Blumenbergian account, this does not render the notion of the absolute superfluous in the context of the latter. Quite the contrary: according to Blumenberg, the absolute is a permanent backdrop against which, and in opposition to which, humankind persistently positions itself. If, on the basis of Blumenberg's short description of the dependence of the emergence of mankind on the emergence of the absolute - and vice versa - we posit a degree of structural affinity between the Blumenbergian account of our relation to the absolute and the Hegelian account of that relation as I interpreted it above, we can proceed to consider whether the Blumenbergian account enhances our understanding of Hegel. Although the structural affinity, in itself, does not obviate the many important differences between the two accounts, it does, in my estimation, suffice for us to deem Blumenberg's account a plausible source of insight into Hegel's account.

Blumenberg maintains that humans, since emerging on the landscape of pre-history, have sought to sidestep a challenge that appeared on the scene concurrently, namely, the challenge of directly contending with the problem of the absolute. The history of human culture records humankind's incessant efforts to evade the absolute. Indeed, this history can be understood as a continuous struggle to avert the danger of being further exposed to, and thus vulnerable to, 
the absolute. Since these ongoing evasive efforts have a history of their own, it is worthwhile, in the quest to elucidate our relation to the absolute, to contemplate the beginnings of this history. Moreover, the unceasing and assiduous effort to evade the absolute in essence amounts to perpetual affirmation of its existence. In his Work on Myth, (1985) Blumenberg conceptualizes this duality by, inter alia, distinguishing between the work of myth and work on myth. Investigating the work of myth involves an attempt to trace the earliest efforts to evade the absolute, though with the full knowledge that the historical moment when the absolute emerged, setting the stage for the ensuing evasive manoeuvres, can never be pinned down. This inability does not reflect a cognitive limitation, but rather an ontological limitation, for human existence was secured only as a result of the original act of evasion, namely, creation and maintenance of distance between humans and possible predators. Consequently, despite our persistent efforts, and no matter how much time has elapsed since they began, or how much longer they will continue, we can never be certain that the threat of the absolute has been completely removed. This decisive fact compels man to engage in unceasing "work on myth,» as the primordial myths are our earliest source depicting the evasive endeavour. The repeatedly failed attempts to put an end to the absolute attest to the profound need to preserve the very earliest attempts, which date back to the dawn of human civilization. The ongoing "work on myth,» in its exceedingly varied forms, constitutes the historic concretization of the evasive enterprise-maintaining distance between ourselves and that which threatens us, constructing a safe space within which our existence is possible. But as I noted above, the endless nature of this work, and the inexorable lack of a criterion that can definitively establish whether conditions are ripe for discontinuing the practice of doggedly keeping our distance from the absolute, affirms the absolute no less resolutely. As Blumenberg puts it:

Man is always already on this side of the absolutism of reality, but he never entirely attains the certainty that he has reached the turning point in his history at which the relative predominance of reality over his consciousness and his fate has turned into the supremacy of the subject. There is no criterion for this turning, for this 'point of no return' (Blumenberg 1985, 9).

One would be hard-pressed to find a more unequivocal affirmation of the absolute. The absolute, à la Blumenberg, is such that any attempt to dismiss it or render it extraneous, by claiming that it is no longer meaningful or that its utility has been fully exhausted, is thwarted by the enmeshment of human self-understanding and the notion of the absolute. 


\section{Back to Hegel’s Absolute}

Let us return to the quandary addressed in this article. On the one hand, any attempt to defend the Hegelian position seems to require a comprehensive exposition of the notion of the Absolute, but on the other, it seems that any such exposition is doomed to failure from the outset. While there is a broad consensus that the concept of the Absolute is a cornerstone of Hegel's thought, attempts to provide a convincing interpretation have floundered. Two main approaches to the Hegelian Absolute have emerged. One suggests that, in light of its foreignness to the contemporary philosophical mindset, it be abandoned; the other seeks to denude it of its substantive metaphysical import, and interprets it as referring only to a specific state of affairs within the conceptual framework of objective Spirit. As we have also seen, however, it is impossible to downplay the significance of the Absolute, or dismiss it altogether, without jeopardizing the distinctive Hegelian outlook and the core rationale underlying Hegel's philosophy. Yet we cannot embrace a reading of the Absolute that does not allow us to invoke this concept without an accompanying sense that it is alien, vacuous, preposterous.

There is, however, a plausible option available to us: bearing in mind the Blumenbergian conception of the absolute, we can re-visit, and perhaps embrace, the Hegelian stance that comprehending the Absolute is the goal of philosophy. Blumenberg's account allows us to interpret Hegel's Absolute as activity, namely, the ongoing effort to successfully distance ourselves from that which is humanly unbearable. Engagement in this enterprise unfailingly affirms those involved in the project, while at the same time affirming the reality of the absolute itself. Against this backdrop, Odo Marquard's distillation of the essence of Blumenberg's philosophical project is, I believe, equally true vis-à-vis Hegel. Marquard characterized this project - as Blumenberg himself characterized human culture in general - as the ongoing attempt to liberate ourselves from, or to reduce the burden imposed on us by, the absolute in its myriad forms. We do so by seeking to create a safe space, a buffer zone, between ourselves and the absolute.

Der Grundgedanke der Philosophie von Hans Blumenberg schien mir und scheint mir der Gedanke der Entlastung vom Absoluten zu sein. Die Menschen halten das Absolute - als Wirklichkeit und als Gott - nicht aus: sie müssen Distanz zu ihm gewinnen. (Marquard 1999, 19)

This article has not sought to settle the question of the meaning and significance of Hegel's notion of the Absolute. Rather, it has sought to shed new light on the possibility of a relationship with the Absolute, that is, the possibility that the Absolute is something - some entity that we, as subjects, can have a real 
relation to. To make my case for the plausibility of my reading of the Absolute, I began by offering an interpretation of Hegel's «System Fragment.» I then attempted to add substance to the idea of such a relationship by adducing the thought of Hans Blumenberg, a strikingly 'non-Hegelian' thinker. After showing that Blumenberg, too, struggled with the question of our connection to the absolute, albeit in a completely different context, I argued that Blumenberg's reading of the absolute as a backdrop against which humankind persistently positions itself, suggests a meaningful new direction in the ongoing efforts to interpret the Hegelian Absolute.

\section{BIBLIOGRAPHY}

Blumenberg, Hans. 1983. Legitimacy of Modern Age, trans. by Robert M. Wallace. Cambridge MA: MIT Press

Blumenberg, Hans. 1985. Work on Myth, trans. by Robert M. Wallace. Cambridge MA: MIT Press.

Fulda, Hans Friedrich. 2003. Georg Wilhelm Friedrich Hegel. Munich: C. H. Beck.

Hegel, G.W.F. 1970. Werke in zwanzig Bänden. Auf der Grundlage der 'Werke' von 1832-1845 neu edierte Ausgabe, hrsg. v. Eva Moldenhauer und Karl Markus Michel. 20 vols. Frankfurt/M: Suhrkamp; cited as TWA.

HegeL, G.W.F. 1961 [1800]. «Fragment of a System,» trans. Richard Kroner, in On Christianity: Early Theological Writings by Friedrich Hegel, trans. by T. M. Knox, with an introduction and fragments trans. by Richard Kroner, 309-19. New York: Harper.

HegeL, G.W.F. 1997 [1830]. Encyclopedia of the Philosophical Sciences $\$ 553$, in Peter C. Hodgson (ed.), G.W.F Hegel: Theologian of the Spirit, trans. J. Michael Stewart and Peter C. Hodgson. Minneapolis: Fortress Press.

MARQUARD, Odo. 1999. «Entlastung vom Absoluten. In memoriam Hans Blumenberg,» in Franz Josef Wetz \& Hermann Timm (eds.), Die Kunst des Überlebens, Nachdenken über Hans Blumenberg, 17-27. Frankfurt a. M.: Suhrkamp.

Pippin, Robert. 2015. «Finite and Absolute Idealism: The Transcendental and the Metaphysical Hegel,» in the Transcendental Turn, ed. S. Gardner and M. Grist. Oxford University Press.

Pippin, Robert. 2010. «The 'Logic of Experience' as 'Absolute Knowledge' in Hegel's Phenomenology of Spirit,» in Hegel's Phenomenology of Spirit: A Critical Guide, ed. Dean Moyar and Michael Quante. Cambridge: Cambridge University Press. 
Shankes, Andrew. 1991. Hegel's Political Theology. Cambridge University Press.

Taylor, Charles. 1999. "Comment on Jürgen Habermas, From Kant to Hegel and Back again,» European Journal of Philosophy 7/2 (1999): 158-60.

Theunissen, Michael. 1970. Hegels Lehre vom absoluten Geist als theologischpolitischer Traktat. Berlin: de Gruyter.

Theunissen, Michael. 1978. Sein und Schein: die kritische Funktion der Hegelschen Logik. Frankfurt am Main: Suhrkamp.

Pini Ifergan is Senior Lecturer at Bar-Ilan University, Israel

RESEARCH INTERESTS:

Post-Kantian German Philosophy, Philosophical Anthropology

AdDress:

Department of Philosophy

Bar-Ilan University

Ramat Gan, Israel

\section{Recent Publications:}

Autonomy, Alienation, and the Ethical Life: The Jena Lectures 1803-1806. Palgrave Macmillan, London, 2014. 264 pp.

«Hans Blumenberg's Philosophical Project: Metaphorology as Anthropology», Continental Philosophy Review 48 (June 2015): 359-377. 
